\title{
Experimental Analysis of Modified Stepped Solar Still
}

\author{
Bhavik Bhalara $^{\mathrm{a}}$, Rajiv Varshney ${ }^{\mathrm{b}}$, Arun Kumar Yadav \\ ${ }^{a}$ M.E. Scholar, Radharaman Institute of Technology and Science, Bhopal \\ ${ }^{b}$ Associate Prof., Radharaman Group of Institutes, Bhopal \\ ${ }^{c}$ Asst. Prof, Radharaman Institute of Technology and Science, Bhopal
}

\begin{abstract}
Fresh water is the basic requirement of human life. Water for drinking purpose, industrial and agricultural purposes demands ample quantity of fresh water. The solar desalination systems have the advantage of low maintenance and operational cost. In spite of high investment cost of solar stills, they are friendly to the nature. In the present article, a modified stepped solar still has been designed, fabricated and tested. The modification includes fabricating steps on which small earthen lamps are placed. The maximum temperature on the steps was found to be $67^{\circ} \mathrm{C}$. In case of conventional solar still the maximum temperature recorded was $53^{\circ} \mathrm{C}$. The maximum temperature of water at the steps was $26.41 \%$ higher than the basin temperature of conventional solar still. The maximum productivity of the modified solar still was $326.66 \%$ higher than conventional solar still. The optimum water input flow was found to be $250 \mathrm{ml} / \mathrm{hr}$.
\end{abstract}

\section{Introduction}

Fresh water is primary requirement of human race. Water for drinking purpose and other industrial and agricultural purposes demands large quantity of fresh water [1]. The solar desalination systems have the advantage of low maintenance and operational cost. Although solar stills have high investment cost, they are compatible with the environment [2]. About 6.3 billion people are living on earth in which 400 million people are at living in water scarce areas which would rise to four billion by mid-century [3]. The fabrication of solar still is simple and can be constructed by locally available materials and unskilled people. Solar stills are widely used for desalination in small scale. [4]. According to an estimation, about $97 \%$ of available water sources are saline and/or consist of harmful bacteria and $2 \%$ are in the form of frozen glaciers and polar ice. Hence, only $1 \%$ of the earth's water can be used for drinking and domestic purposes [5].The arising requirement for water is primarily due to the increase of population and fast growth of industries [7]. The heat energy of sun can be used in solar collectors, solar cooking, desalination and cooling systems [8]. Generally, for steam generation, water heating processes and CPCs are used, as they are capable of producing higher temperatures in comparison of flat plate collectors, they can also be used for desalination purpose [9].Most of the arid, remote and semi-arid regions are lack natural fresh water in the southern part of the country and are dependent heavily on underground water for drinking purpose [10]. Higher productivity is obtained in multiple-effect diffusion solar still (MEDS) [11]. Solar stills are largely used for water purification in rural and remote areas with limited demand and low population when the potential of brine water sources and solar energy are available [12].

\section{Literature review}

There has been a lot of work in the field of solar stills to enhance its performance. Researchers have improved the performance by various means such as change in geometry, employment of mirrors in various orientation, use of waste heat etc. Park et al. (2016) designed a multiple-effect diffusion (MED) hybrid solar still with dual heat sources of solar thermal energy and waste heat. Performance tests with waste heat were performed with three operational parameters: (1) the seawater level in the basin (2) the seawater flow rate to the wick and (3) the amount of heat input into the hybrid still. It was observed that the productivity of the hybrid still increases with the increasing heat input, which recorded productivity of $18.02 \mathrm{~kg} / \mathrm{m}^{2}$ at waste heat amount of $22.37 \mathrm{MJ} / \mathrm{d}$. The maximum productivity of distillate was obtained at the lowest seawater level with the experiment including waste heat source. The maximum performance of the MED solar still was achieved at the operation condition obtaining maximum productivity at the second effect plate [13]. El-Agouz modified a stepped solar still using a storage tank for salt and sea water with continuous water circulation. Investigation was made on effect of installing a storage tank and cotton black absorber for modified stepped solar still on the distillate productivity. The indication was given by the results that, the productivity of the modified stepped still was higher than conventional solar still by $43 \%$ and $48 \%$ for sea and salt water with black absorber respectively, while $53 \%$ and $47 \%$ of sea and salt water, respectively with cotton absorber. The daily efficiency for conventional solar still was $20 \%$ lower than the modified stepped still. At a feed water flow rate of 3 LPM for salt water and 1 LPM for sea water, maximum efficiency of modified stepped still was obtained [8]. 
Arunkumar et al. studied the compound parabolic concentrator-concentric tubular solar still united with a single slope solar stills performance. The operation of the experimental setup was conducted in cold water flow over the concentric arrangements of the inner tubes. Single slope solar still was fed with this pre-heated water. It was observed that the output was directly proportional to the evaporative heat transfer coefficient. Phase change material was incorporated in the single slope solar still to increase the distillate at night hours [9].Bechki et al. studied the effect of desert climatic conditions on the performance of a simple basin solar powered distillation unit with three series of [10].

Chong et al. developed a multiple-effect diffusion solar still with a bended-plate design in multiple effect diffusion units (MDU) to solve the peel-off problem of wick material. The MDU was coupled with a vacuum tube solar collector so that for high productivity it could produce a high temperature gradient. A heat pipe was used to transfer the solar heat to the MDU [11]. Dashtban and Tabrizi designed a weir-type cascade solar still, combined with latent heat thermal energy storage system, for improving the productivity. Use of a heat storage system with $18 \mathrm{~kg}$ mass of paraffin wax under the absorber plate kept the operating temperature of the still high enough to produce distillate water during the lack of sunshine, particularly at night. The daily productivity obtained was 6.7 and $5.1 \mathrm{~kg} / \mathrm{m}^{2}$ day of the solar still with and without Phase change materials, respectively. The results showed that the productivity of the still with Phase change material was theoretically $31 \%$ higher than that of without Phase change material [12].

Elango and Murugavel made a study on the basin material to improve productivity of still. Single and double basin double slope solar stills having same basin were fabricated using glass. Experiments were carried out by changing the water depths from 1 to $5 \mathrm{~cm}$ under insulated and un-insulated conditions. The insulated double basin and non-insulated solar stills gave a higher production rate of $17.38 \%$ and $8.12 \%$ than the single basin still [14].Hansen et al. developed an inclined type solar still which was experimentally studied using different wick materials on different absorber plate configurations. The new materials were selected for heat transfer co-efficient, water repellence, porosity, capillary rise, absorption to select a suitable material for the solar desalination application. Different wick materials were chosen for the analysis [15].

Kabeel et al. designed a stepped basin used to improve the performance of solar still. An experimental as well as theoretical investigation was carried out. The influence of depth and width of trays on the performance of the stepped solar still was investigated. Feed water temperature to the stepped still was varied using a vacuum tube solar collector. For further augmentation of the yield, a wick on the vertical sides was added to the stepped still. A good agreement between the experimental and theoretical results was observed [16].

\section{Materials and method}

A modified solar still (MSS) has been designed, fabricated and its performance is compared with the conventional solar still (CSS). Dashtban and Tabrizi 2011 designed a weir type solar still integrated with latent heat thermal energy storage system and used the steps having dimensions of $103 \mathrm{~cm}$ width, horizontal and a vertical surface with the lengths of 5 and $3 \mathrm{~cm}$, respectively in the solar still [12]. In the present work we have used the above dimension of steps incorporated with earthen lamps placed over them and latent heat thermal energy storage system was omitted.

The present set up is fabricated with the GI sheet of $0.5 \mathrm{~mm}$ thickness. The still is insulated with the wood. The steps are manufactured and were fixed on the upper portion of the container which was used as upper basin. The stills top portion is covered with the toughened glass of $4 \mathrm{~mm}$ thickness. The experiments were performed on the still from 9:30 AM in the morning to 3:30 PM. The distillate was measured with the help of measuring cylinders. The basin temperatures were measured at every hour for the modified as well as the conventional solar still. Solar radiation was measured with the help solariemeter. Humidity was measured with the help of Humidity meter. The wind velocity was measured with the help of anemometer. All these parameters were measured at every hour. The experimental setup and instrumentation are shown in figures 1 and 2 , respectively. 


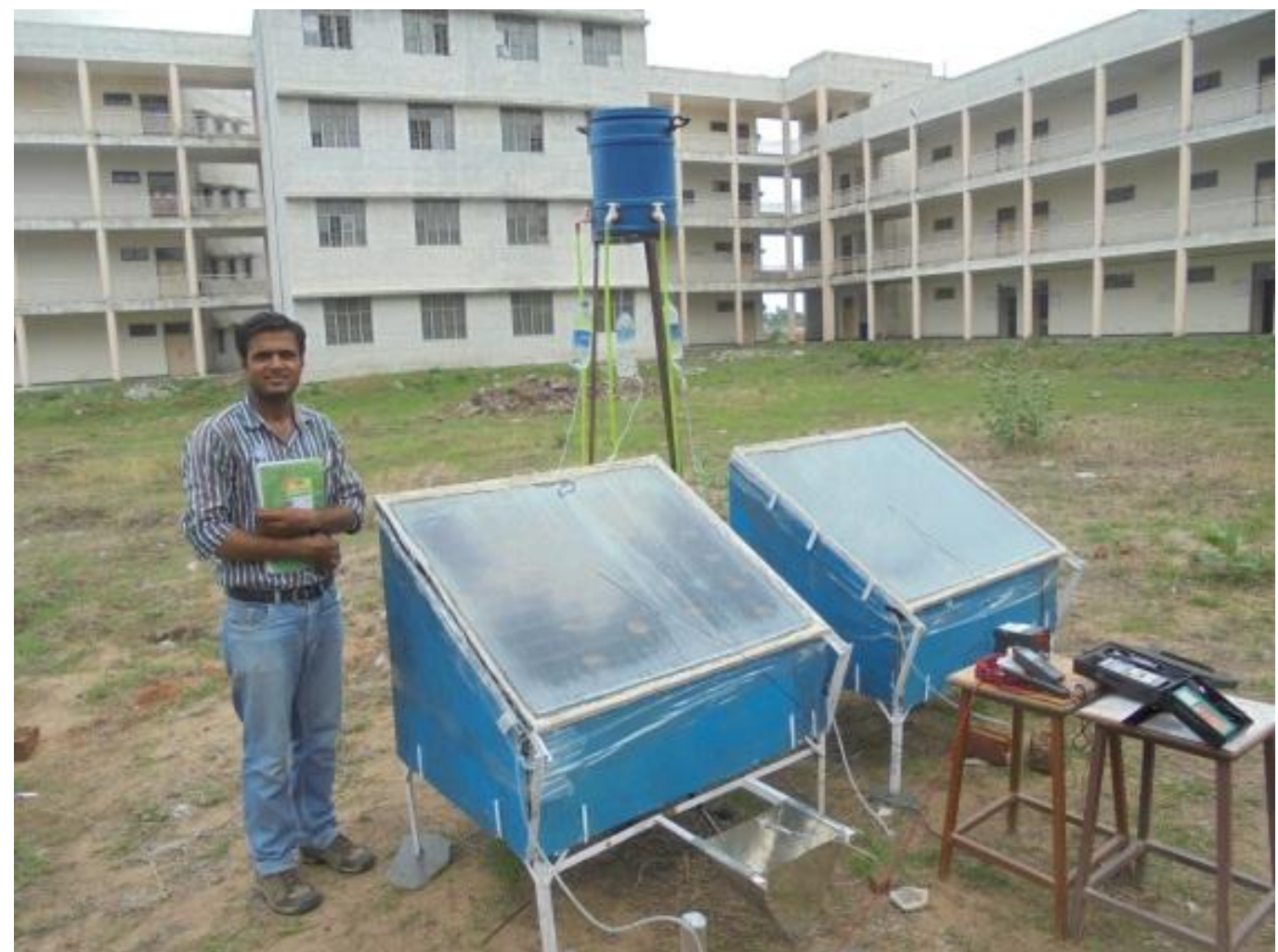

Fig.1.Experimental setup with instrumentation

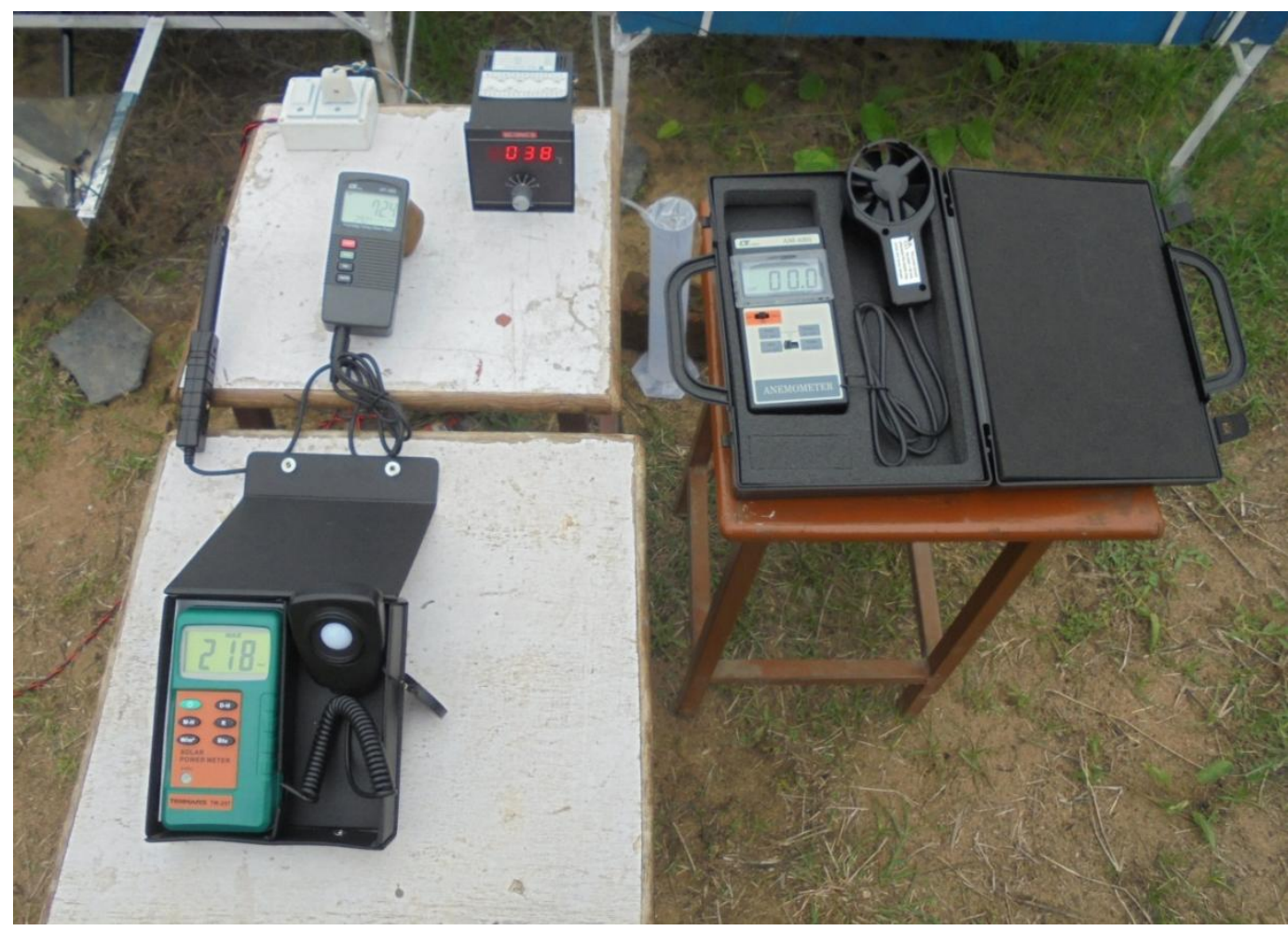

Fig. 2. Instruments used during the experiments

\section{Results and discussion}

The temperature of water on the steps in MSS and in the basin of CSS is a very important parameter as it decides the performance of the modified solar still. If this temperature is higher than $80^{\circ} \mathrm{C}$, there are good chances of scale formation at the surface of steps. Moreover, if the temperature is too low, it will affect the productivity of the still [13]. The temperatures were noted during the day time from 09:30 AM to 03:30 PM. 
The maximum temperature on the steps was found to be $67^{\circ} \mathrm{C}$ at $01: 30 \mathrm{PM}$. In case of CSS the maximum temperature was recorded as $53^{\circ} \mathrm{C}$ at $01: 30 \mathrm{PM}$. The maximum temperature of water at the steps was $26.41 \%$ higher than the basin temperature of CSS. Figure 3 shows the variation of step temperature and basin temperature with respect to time.

The maximum hourly productivity of fresh water for MSS was $320 \mathrm{ml}$ which was recorded between 12:30 noon to 01:30 PM. The maximum productivity for CSS was also found to be in the same temperature range, which was $75 \mathrm{ml}$. Thus, the maximum productivity of the MSS was $326.66 \%$ higher than CSS. The optimum water input flow was found to be $250 \mathrm{ml} / \mathrm{hr}$. The variation of productivity of MSS and CSS with respect to time is shown in figure 4.

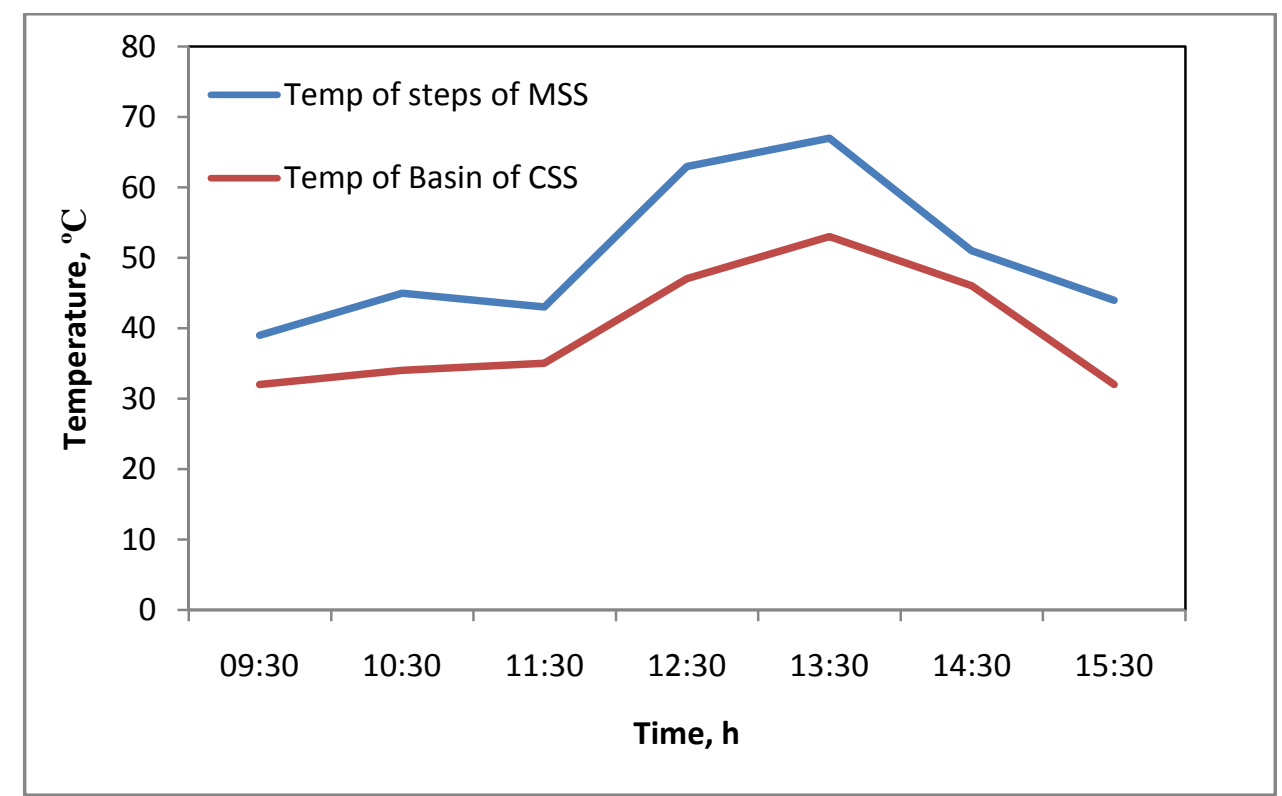

Fig.3. Variation of temperature of the steps of MSS and basin of CSS with time

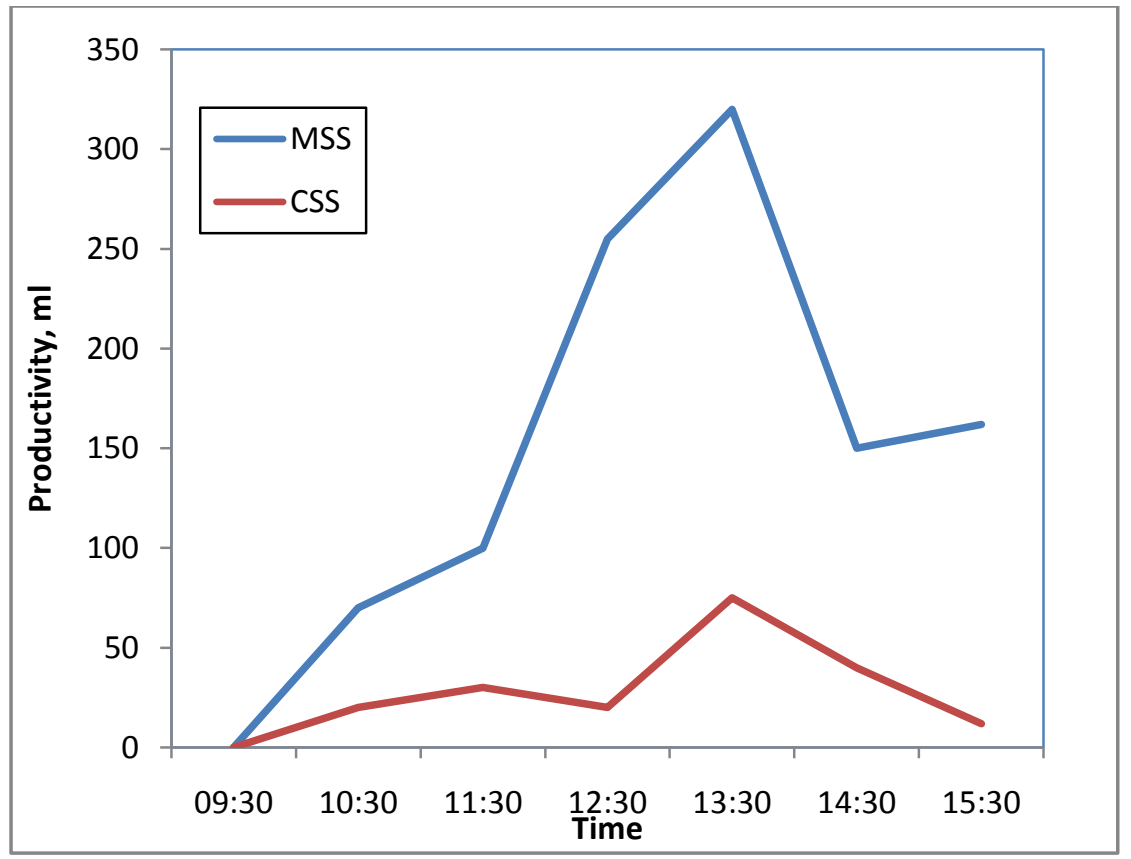

Fig.4. Variation of productivity (ml) of MSS and CSS with time 


\section{Conclusion}

For drinking and other industrial purposes, fresh water is foremost requirement. The solar desalination systems have the advantage of low maintenance and operational cost. In spite of high investment cost of solar stills, they are friendly with the nature. In the present study a modified stepped solar still has been designed, fabricated and tested. After conducting experiments, following conclusions are drawn.

- The modification includes fabricating steps on which small earthen lamps are placed. The maximum temperature on the steps was found to be $67^{\circ} \mathrm{C}$ at 01:30 PM. In case of conventional solar still the maximum temperature was recorded as $53^{\circ} \mathrm{C}$ at $01: 30 \mathrm{PM}$.

- The maximum temperature of water at the steps was $26.41 \%$ higher than the basin temperature of conventional solar still. The maximum productivity of the modified solar still was $326.66 \%$ higher than conventional solar still.

- The optimum water input flow was found to be $250 \mathrm{ml} / \mathrm{hr}$.

Finally, it can be stated that the present modified solar still can be used for the various purposes with low cost and high efficiency at different sectors on human life.

\section{References}

[1]. El-Zahaby A.M, Kabeel A, Bakry A.I, El-agouz S, Hawam O.M, "Augmentation of solar still performance using flash evaporation", Desalination 257 (2010) pp 58-65.

[2]. Ziabari Fatemeh Bakhtiari, Sharak Ashkan Zolfaghari, Moghadam Hamid, Tabrizi Farshad Farshchi, "Theoretical and experimental study of cascade solar stills", Solar Energy 90 (2013) pp 205-211.

[3]. http://www.ceemeng.mit.edu/Stevens.pdf.

[4]. Velmurugan V, Pandiarajan S, Guruparan P, Subramanian L. Harihara, Prabaharan C. David, Srithar K, "Integrated performance of stepped and single basin solar stills with mini solar pond", Desalination 249 (2009) pp 902-909.

[5]. Velmurugan V, Gopalakrishnan M, Raghu R, Srithar K, "Single basin solar still with fin for enhancing productivity", Energy Conversion and Management 49 (2008) pp 2602-2608

[6]. Omara Z.M, Eltawil Mohamed A, ElNashar El Sayed A, "A new hybrid desalination system using wicks/solar still and evacuated solar water heater", Desalination 325 (2013) pp. 56-64.

[7]. Abderachid Trad, Abdenacer Kaabi, "Effect of orientation on the performance of a symmetric solar still with a double effect solar still (comparison study)", Desalination 329 (2013) pp 68-77.

[8]. El-Agouz S.A, "Experimental investigation of stepped solar still with continuous water Circulation", Energy Conversion and Management 86 (2014) pp 186-193.

[9]. Arunkumar T, Velraj R, Denkenberger D, Sathyamurthy Ravishankar, Vinothkumar K, Porkumaran K, Ahsan Amimul, "Effect of heat removal on tubular solar desalting system", Desalination 379 (2016) pp 24-33.

[10]. Bechki D, Bouguettaia H, Blanco-Galvez J, Babay S, Bouchekima B, Boughali S, Mahcene H, "Effect of partial intermittent shading on the performance of a simple basin solar still in south Algeria", Desalination 260 (2010) pp 65-69.

[11]. Chong Tze-Ling, Chong Bin-Juine, Wu Po-Hsien, Kao Yeong-Chuan, "Multiple-effect diffusion solar still coupled with a vacuumtube collector and heat pipe", Desalination 347 (2014) pp 66-76.

[12]. Dashtban Mohammad, Tabrizi Farshad Farshchi, "Thermal analysis of a weir-type cascade solar still integrated with PCM storage", Desalination 279 (2011) pp 415-422.

[13]. Park Chang-Dae, Lima Byung-Ju, Chung Kyung-Yul, Lee Sung-Soo, Kimb Young-Man, "Experimental evaluation of hybrid solar still using waste heat", Desalination 379 (2016) pp 1-9.

[14]. Elango .T, Murugavel K. Kalidasa, "The effect of the water depth on the productivity for single and double basin double slope glass solar stills", Desalination 359 (2015) pp 82-91

[15]. Hansen R. Samuel, Narayanan C. Surya, Murugavel K. Kalidasa, "Performance analysis on inclined solar still with different new wick materials and wire mesh", Desalination 358 (2015) pp 1-8.

[16]. Kabeel A.E, Khalil A, Omara Z.M, Younes M.M, "Theoretical and experimental parametric study of modified stepped solar still”, Desalination 289 (2012) pp 12-20. 